CANADIAN IMMIGRATION EXPERIENCE: CASE STUDY OF PAKISTANI SKILLED IMMIGRANTS AND THEIR JOB EXPERIENCE.

\author{
by \\ Saadat Hussain Qadri \\ B.A University of Sindh, 2003 \\ A Major Research Paper \\ presented to Ryerson University \\ in partial fulfillment of the requirements for the degree of \\ Master of Arts \\ program of \\ Immigration and Settlement Studies.
}

Toronto, Ontario, Canada, 2020

(C) Saadat Qadri, 2020 


\section{AUTHOR'S DECLARATION FOR ELECTRONIC SUBMISSION OF A MAJOR RESEARCH PAPER (MRP)}

I hereby declare that I am the sole author of this Major Research Paper. This is a true copy of the MRP, including any required final revisions, as accepted by my examiners.

I authorize Ryerson University to lend this MRP to other institutions or individuals for the purpose of scholarly research

I further authorize Ryerson University to reproduce this MRP by photocopying or by other means, in total or in part, at the request of other institutions or individuals for the purpose of scholarly research.

I understand that my MRP may be made electronically available to the public.

Saadat Hussain Qadri. 


\title{
CANADIAN IMMIGRATION EXPERIENCE: CASE STUDY OF PAKISTANI SKILLED IMMIGRANTS AND THEIR JOB EXPERIENCE.
}

Saadat Hussain Qadri, 2020

Master of Arts Immigration and Settlement Studies

\begin{abstract}
:
Canada has been perceived as the land of immigrants. Internationally trained immigrants contribute to the Canadian economy with their skills. The Literature available suggests that Canadian immigration policy, however, has been ineffective given integrating many of these foreign qualified skilled immigrants into their professions. As a result, immigrants with years of education and relevant experience in their job, face difficulties like professional hardships, changing careers from one to another and face discrimination in the Canadian labor market. This research focuses on the lived experiences of members of a visible minority group from Pakistan. The finding indicates the underutilization of the skills and experiences of immigrants come under the economic class of immigration. The research also highlights the difficulties faced in securing employment in their field of study. Finally, it highlights the directions that could help overcome these obstacles to employment.
\end{abstract}

Keywords: Immigration policy, Employment difficulties, Visible minorities, Lived experience. 


\section{Acknowledgement:}

First, I would like to convey my heartfelt appreciation to my research supervisor, Prof. John Isbister, who has been extraordinarily encouraging and made the process of writing this MRP much simpler. He offered me detailed, important knowledge and academic guidance that enabled me as a graduate student and as a researcher.

I would also like to thank Prof. Amy Peng for working as the second reader for this research and giving me her helpful comments and suggestions.

I would also like to mention my worthy program director Prof. Harald Bauder for his dedication with every new student in the cohort and last but not the least my program administrator Igor Rosic who has been the most supportive among all faculty members during my study period.

Finally, and most importantly, I would like to thank my wife along with my daughters for their continuous support and unconditional encouragement during my studies. I also would like to thank my family for their continued support and guidance in bringing me to this stage.

This research could not have been possible without the contributions of the aforementioned people. 


\section{Table of Contents}

Author's declaration: ii

Abstract:

Acknowledgement: $\quad$ iv

$\begin{array}{ll}\text { Introduction: } & 1\end{array}$

Research methodology: $\quad 5$

Sampling: $\quad 6$

$\begin{array}{ll}\text { The Interview Process: } & 7\end{array}$

$\begin{array}{ll}\text { Research Limitations: } & 8\end{array}$

Pakistani skilled migrants in Canada: $\quad 9$

A Brief Socio-Economic Profile of the Participants: 11

$\begin{array}{ll}\text { Employment issues: } & 13\end{array}$

What is Skill-related discrimination in workplace: $\quad 14$

$\begin{array}{ll}\text { Skill discounting: } & 15\end{array}$

$\begin{array}{ll}\text { Occupational mismatch: } & 17\end{array}$

Significance of social networking in job search: 20

Role of community development agencies: $\quad 21$ 
Issues with Accreditation evaluation:

Role of Canadian education:

Student financial assistance:

Conclusion:

Appendices

A1 Study questionnaire:

A2 Study flyer:

A3 Consent Agreement:

A4 Confirmation of agreement:

References:

41 


\section{Introduction:}

Skilled Immigrants are a primary driving force for Canada's economic progress. Foreign skilled workers are increasingly important factors in promoting all countries economic growth. As per (S. Guo 2009, 2013a, 2013b; Guo and Shan 2013; Li 2008) Despite Canada's communicated inclination for extraordinarily highly skilled workers and in spite of way that migrants bring significant human capital assets to the Canadian economy, various studies show that numerous internationally trained workers experience deskilling and lowering of their foreign skills. Understanding in the wake of moving to Canada. As the globalization of migration expands, Canada has participated in a worldwide challenge for the most able, talented, and creative immigrants to help improve its work shortages. Economic migrants bring more human capital than family-class workers and refugees. Since the 1990s, Canada has been successful in pulling in exceptionally skilled laborers from everywhere throughout the world, especially experts in fields like architects, chartered accountants, financiers, social specialists, IT experts.

Canada requires a continuous stream of well-trained immigrants. The nation's low fertility rate of 1.6 youngsters per female that is well under the substitution rate of 2.1. The fertility rate was 3 youngsters or more for each woman from the mid-1940s to the mid-1960s. At that point, fertility fell quickly; and has stayed underneath the rate for population stability, throughout the next 30 years. As indicated by the literature, with a growing population and low fertility rates, immigration assumes a significant job in guaranteeing that Canada's population and work power keep on developing. Given that migrant newcomers are, by and large, more youthful than the Canadian born population, immigration can help alleviate a portion of the difficulties of a maturing population. 
Canada has been perceived as a homme that is known for skilled immigrants from the early days of its development, although, the immigration rate has fluctuated over time. (Boyd and Vickers 2000) contend that traditionally, migrants from most of the European nations came to Canada, either looking for agriculture land and rich regular assets or to keep away from the staggering wars back at home. In the latest history of Canadian migration, the strategies are basically been molded as per work power prerequisite and the yearning for economic improvement. (Kobayashi 2012) states that, migrants in Canada add to roughly 50 percent of the country's population growth and just about 70 percent of its manpower development. The point system of selection, presented in 1967 made immigration increasingly more specific, supporting profoundly highly skilled foreigners from the rest of the world. (Setia 2011, Subedi and Rosenberg 2014) Canadian policy is based on the hope that immigrants will contribute to the prosperity of the country because of their skills. New foreign trained immigrants land in Canada to seek after a superior profession, improved personal satisfaction, upgraded security, a more joyful and ensured future, and open doors for their ages to come. (Wald and Fang 2008, Asanin and Wilson 2009) express that, However, research has demonstrated that the greater part of the talented migrants, wind up in position that, do not use their insight, abilities, and experience. Many recently landed foreign born, highly skilled professionals are proficient in their particular fields like specialists, engineers, attorneys, supervisors, and educators, end up jobless or underemployed, driving taxicabs or conveying pizzas in Canadian urban areas (Nerad and Janczur 2000). (Bauder 2003) clarifies that, working in low-skilled service occupations as a rule brings about low financial status and, subsequently, wellbeing status disintegrates. Research has shown that migrants battle in their early year in the host country. (Xu 2012) finds that, in excess of 63 percent of cab drivers are migrants in the city of Ottawa. (Konadu-Agyemang 2006; Xu 2012) contend that significant number of 
skilled immigrants are utilized as cabbies, accommodation store laborers, and service station laborers in significant Canadian urban communities. A recent report by (Girard and Smith2013) found that visible minority immigrants are significantly less liable to tie down passage to a vocation in a directed occupation in contrast with other migrants and the Canadian-born population.

(Wald and Fang 2008; Asanin and Wilson 2009) express that, most of the immigrants are overeducated for the employments they are doing in Canada and subsequently, are underutilizing their insight, abilities, and experience. 


\section{$\underline{\text { Research Methodology }}$}

\section{Research Design and Methods:}

In this segment, I present the methodology used in this research. Data collection methods, sampling strategies, data analysis and the limitations of the study are discussed. During this study, standardized semi-structured interviews were organized. There was a combination of both closed and open-ended questions with more emphasis on the latter to permit an unlimited number of responses that allowed for unanticipated findings. This technique included recording occasions and issues that are genuine by catching the encounters of the individuals. (Neuman, 2006)

Applicants under this method had the opportunity to discuss their experiences as professional trained immigrants and the obstacles they faced in finding employment. The questions to the skilled immigrants from Pakistan addressed issues related to their demographics, immigration, education, previous profession and barriers to employment, employment experience, and settlement experience. The actual questionnaire is attached as Appendix 1. Participants were given sufficient opportunity to express their concerns and issues. I, being a researcher informed participants to discuss any matters relevant to their socio-economic, immigration and settlement issues.

The purpose of this research was multiple in nature with an emphasis on being exploratory. While it is exploratory in nature due to limitations of time and resources, it should initiate more research 
on the subject so as to understand better that why new immigrants who are professionally trained are facing multiple difficulties which restrict them into working in Canadian labour market in Toronto and what solutions do they recommend to help overcome obstacles to professional employment. This study received ethical approval from the Ryerson University's Ethics Committee and all participants gave consent for their participation.

\section{Sampling:}

(Neuman, 2006) explains that "sampling is a list that intently approximates every one of the components in the population ". Therefore, I had to be creative, accommodating and used distinct approaches to achieve an applicable sample. I distributed the flyer at various locations such as outside the bus stops, Union Station and subway stops. Meanwhile, the interested applicants were asking questions about flyer, so I was telling them about the study while they were waiting for their buses, cabs and other source of traveling approach them and I was giving them the flyer. (Appendix 2). My official Ryerson university email address was provided for potential participants to schedule an appointment at their convenience. I managed to get only two participants through this strategy. Another strategy was to place the flyers on the windshield of cars that were parked on public parking area, outside malls, temples, churches, and mosques. A flyer about the study was also placed on notice board inside one of the largest malls in Toronto. The response from this strategy was particularly good and I received four emails received from a respondent willing to participate in the study.

It was significant to create a definite level of trust for contributors to share their narratives without fear. I repeated my obligation to confidentiality as laid out in the consent form. The respondents were informed that they were under no obligation to finish the interview and had the right to walk 
away from it at any time during the procedure. In order to examine and analyse the lived experience I conducted the interviews from volunteer participants.

\section{The Interview Process}

In order to achieve the objectives of my research, I interviewed six volunteer respondents at different locations of GTA and those interviews were performed at different locations of Toronto library. All the respondents had completed at least post-secondary education from Pakistan and Canada as well. One such potential participant who was a social worker declined to mentioned real name and I had rescheduled the interview once again after few days of interview. Initially, I planned to interview maximum of 20 respondents; however, difficulties in recruiting, willing and appropriate participants and the hectic schedule of the working people and limitations of time resulted in six interviews being completed. Each interview with the skilled workers from Pakistan took approximately 40 minutes. Interviews were conducted at the appointed time at various locations of Toronto libraries in order to place a safety first for both the interviewer and respondents. The locations of public library were chosen depending on the preference of the participants. A couple of interviews were conducted via skype as well.

Secondary data gathered in this paper are from various sources such as research papers, government documents, newspaper articles. 


\section{$\underline{\text { Research Limitations }}$}

Since, this is a qualitative research and not a quantitative one, the information gained from the study will provide significant exploratory understandings related to the kinds of difficulties and issues faced by professionally trained immigrants who face complications in getting employment in their own profession. However, given that it was impossible to get a list of all immigrant from Pakistan and living here in GTA who possess postsecondary education, Another limitation that I had anticipated the participant's reluctance to providing certain information such as their immigration status or their earnings. I did not encounter this problem from any potential participant that I approached except one who declined to participate in the survey after initially agreeing to it. To alleviate this reluctance, I first started by giving a brief background about myself, my training and interest in the subject. As an immigrant, I tried to make the participant feel more comfortable and at ease and assured them that this was entirely voluntary and that their names will not be mentioned at any point in the research report. A voluntary consent form (see Appendix 3) was completed with all the six respondents. The principle of voluntary consent is that "people should never participate in research unless they explicitly and freely agree to participate." (Neuman, 2006.) Despite its limitations this study will give valuable insight to other researchers and may act as a catalyst and an entry point to further explore the issues and barriers faced by immigrants who are professionally trained and working in various organizations in Toronto. 


\section{Pakistani skilled migrants in Canada.}

Pakistani permanent residents or with citizenship status in Canada have gathered constrained thought in the research writing. For example, while we know a considerable amount about the endeavors and difficulties Pakistani immigrants face in the Canadian employment environment. (Haider 2012) express that, we know far less about their profession and economic integration experiences, particularly the individuals who are effective in obtaining a career in their very own or related professions. (Qureshi 2010) clarify that to give preference to concentrate exclusively on the skilled migration of Pakistani qualified immigrants provided their nation's political and economic insecurity, that witnessed several Pakistanis moving to Canada. In this research, I characterize struggle completed and tested looked by Pakistani skilled immigrants and their international migration experience as an individual and centered choice taken by highly qualified immigrants to begin another profession in an international country like Canada.

Respondents characterized themselves as immigrants, showing that they utilized the overwhelming conditions in Canadian discussion which are utilized to characterize the minority Other. They were reluctant about their circumstance as a visible minority, network and many focused on the significance of associating with others and not self-isolating as a network. 'Since, once more, we are a minority. Whoever comes here and it requires some investment for them to discover their direction, so there is difficult work to do on their part more than the individuals who are as of now here.

Their new life, jobs, and integration into economic system in the new nation like Canada could be the perseverance of their career in their nation of origin or could be in a totally changed occupation because of a few official and operational obstructions. (Zikic, 2010) clarify that their profession is both risky and strange. As a matter of fact, Pakistani foreigners compare to a gigantic bit of very 
knowledgeable individuals in the Canadian workplace, as indicated by (Statistics Canada, 2015), along these lines making them an engaging community from visible minority to examine. Furthermore, the professional explorations of Canadian occupation marketplace. Accordingly, focusing on Pakistani immigrants grants not just for a further fine-grained research into a population of skilled migrants, yet in like manner offers a more prominent information on their distinctive abilities made on their individual stories. It additionally offers the opportunity to survey imperative workplace issues in a specific and complete approach.

The interview process was extremely pleasant but I was little bit conscious regarding the discussion because it sometimes very unpleasant to recount memories and to answer correctly and participants were mentioned to remember their experiences about their employment and what happened when they really started struggle to find out their relevant employment in their professions here in Canada. (Thorbjörnsson 1999). Contend that while there are worries about individuals' capacity to review occasions from past, tentative evidence indicates that exact review can be made for occasions that happened even 24 years back. All individuals were from Pakistan and have been living in Canada for different time spans. (A compact profile of each part is given in the Appendix.) As noted earlier, Pakistani immigrants are a remarkable get-together to look at.

As per the National Household overview 2011, there are 156,860 Pakistani immigrants dwelling in Canada (Statistics Canada, 2016a). Along these lines, this meeting presents a remarkably and valuable example to talk about because as indicated by (Statistics Canada, 2016b) Asia is the biggest wellspring of workers and Pakistan is among the main ten source nations. Also, concentrating a domestic group, for example, Pakistani, can support to convey procedure pathways and suggestions to receive right profession change concerns appropriate to this group only and Asian immigrants generally. 


\section{A Brief Socio-Economic Profile of the Participants}

The following is a brief demographic profile of the participants, whose names have been changed to maintain anonymity and confidentiality. This socio-economic profile is based on the respondent's own statements. For example, participants themselves identified their "class," which this study has neither challenged nor correlated to their current annual income or occupation in country of origin. Variations exist in terms of sects of religion, i.e., Islam, which have not been further explored. Briefly, this short profile provides a broader context when skilled immigrants voices are heard through their narrations.

(i) Overall, the six volunteer participants have been living in Canada from three to fifteen years. However, four participants — one third of the participants — have been living in Canada from three to fifteen years. The rest have been living in Canada for less than three years. This statistic reflects Canada's shifting immigration policy, i.e., focus on the skilled category, which facilitates these skilled migrations. Just one participant lives in Alberta. The others live in the suburbs of Greater Toronto Area. These are the municipalities where most South Asian immigrants reside, as housing is more affordable in the suburbs than in Toronto.

(ii) The range of ages for all but four respondents were between forty-five to fifty years old. This statistic reflects that these skilled immigrated to Canada at a young age (i.e., between twenty-five to thirty-five years old). All the immigrants have children. Out of six migrants, four migrants have three children, one has four children, and another has two children. The fact that two-thirds of the skilled workers have three children indicates that two major goals of Canada's current immigration policies are being met: to boost Canada's demographic growth and increase the young labour pool that sustains the capitalist economy of Canada. 
(iii) These participants first languages are diverse, including, Urdu, Punjab and sindhi, and reflect that the migrant's ancestries are from Sindh and Punjab - two provinces in Pakistan. Habib( psydonium) narration indicates how this ethnicity based on language can create barriers to making new friendships in Canada: "I think it was strange here that individuals from Pakistan here in Canada, were not encouraging, they needed to live in their particular groups. On the off chance that someone was Urdu, they needed to live in an Urdu hover, Pathans in a Pathan circle." Habib (psydonium) statement points out that language rather than nationality might play a key role in creating social relationships in Canada and reveals that Islam as a religion does not play a binding force for immigrants from Pakistan who are Muslims.

(iv) All of the respondents were Muslims in terms of religion.

(v) In terms of professional background in Pakistan, one respondent has a master from London UK, two are professional engineers, one is a chartered accountant, one is banker, one participant had experience in social work. In Pakistan, these highly qualified immigrants had various professions: engineer, auditor in banking sector, officer in community development.

(vii) Not all of the immigrants migrated directly from Pakistan. one had experiences living in the UK. These skilled migrants reported having positive experiences in Canada as compared with the USA and Australia in certain areas - for example, healthcare in the USA is more privatized than in Canada. In Australia, a new immigrant is barred from several basic entitlements (for details, see Jupp 2002). 


\section{Employment issues:}

There are a variety of issues to employment for professionally trained immigrant. While the particular hurdles to suitable employment and the lived experiences of Pakistani skilled immigrants who are professionals will be discussed later in this paper, a review of the overall literature features some of the key hurdles to employment common for new immigrants as a group.

(Castles 1973; Castles 2004) express that, immigrants are frequently impeded in the workplaces of accepting nations. Newcomer normally face challenges related to human capital deficiencies, non-acknowledgment of qualifications, lacking semantic abilities, and ethnic and racial segregation. Therefore, social propensities in the Canadian workplace keep migrants from accomplishing their total economic promise. In this paper, I share the thought of habitus to workplace strategies and the occupation state of immigrants. I inspect how social practices in the employing procedure and in the working environment disservice immigrant workers in Canada.

Canadian migration policy separates between immigrants who have financial and human capital, who have family connections to Canada, and who are needing helpful help. skilled and capitalrich migrants have an undeniable bit of leeway in the Canadian labour market. I propose further that talented and capital-rich foreigners will in general have social skill that empowers them to progress in the Canadian workplace. Migrants admitted to Canada for family reunification and compassionate reasons, then again, frequently need recognition with the commanding workplace rules and shows. Considering human capital and social imperatives, immigrants create specific work systems and utilize the ethnic and social assets accessible to them.

Newcomers land to Canada for an entire host of reasons however employment opportunities and new profession openings are two of the most significant elements. My research likewise realize 
that immigrants keep on adding to Canada's economy with joblessness levels either underneath or marginally over the figure for all Canadians.

We have conducted the interviews from volunteer participants from Pakistani Diaspora in regard to employment difficulties faced by all of them. one of the Participants Named as Akhter (pseudonym) said and he mentioned that:

"Yes, indeed there is a discrimination in employment search because employers discriminate people on the basis of their background, education, experience and skills, that's how the newly landed immigrants from different parts of world face unnecessary challenges based on their identity. I struggled in my initial time to get job in my professional field, but I was unable to fined one because I did not have Canadian education and experience”,

\section{What is Skill-related discrimination in workplace:}

(Binggeli 2013) share views on workplace discrimination as Work discrimination alludes to out of line differential treatment of present or forthcoming representatives exclusively dependent on their social or economic participation. Ability related victimization of immigrants, the focal point of our examination, has been tended to by researchers from a few orders, for example, HRM (e.g. Hakak \& Al Ariss, 2013; Salaff, Greve, \& Ping, 2002), psychology (e.g. Esses, Dietz, \& Bhardwaj, 2004, Esses et al., 2006) and sociology (e.g. Reitz, 2007). This kind of discrimination has two essential features: either immigrants aptitudes, for example, their scholarly and proficient degrees just as their work understanding, are unjustifiably depreciated (for example aptitude limiting and the degrading based ability mystery) or their aptitudes are esteemed however saw as a risk to local people. 
Another volunteer participants Mr. Faiz (pseudonym) also expressed his views about the discrimination in the job market, his opinion was that.

"When I came here in 2008, I had a 10 years of experience in Mechanical Engineering from one of the oldest Universities in Pakistan, so I was pretty sure to get job in my professional field of expertise, but I was so surprised of not getting any response from my employers their only basic question was that whether I have a Canadian experience or no. So, I asked that how a newly landed immigrant can give you Canadian experience until he or she is not offered employment on the basis of their back-home education and experience”.

\section{Skill discounting:}

Most of the research on skilled based discrimination has inspected 'skill discounting' (for example Li, Gervais, and Duval, 2006), which can be characterized as the downgrading of immigrants, foreign academic education, foreign professional training and foreign work experience. Skill discounting implies that immigrants' aptitudes are assessed more regrettable than those of local people, regardless of whether they are really of a similar quality. It is both an institutional issue (for example Salaff,2002) and an individual-level marvel as biased predispositions against worker candidates (for example Esses., 2006).

(Salaff 2002), in a research of Chinese immigrants to Canada, depicted various cases in which neighborhood foundations (for example proficient panels) didn't perceive foreign degrees. For instance, a Chinese therapeutic specialist, regardless of cutting-edge preparing remembering stays for the USA never recaptured authorization to practice her profession in Canada. Canadian organizations clearly went about as guardians, and regularly bosses demanded Canadian work understanding, bringing about underemployment or joblessness of immigrants (see additionally 
Fang, Samnani, Novicevic, and Bing, 2013). Supplementing the examination by Salaff (2002), Esses, 2006) examined the oppressive conduct of staff chiefs. These staff leaders, especially the individuals who harbored inert partialities, displayed an example of inconspicuous segregation: they degraded the foreign skills of a worker from a non-Western nation, however not those of an immigrant from a Western nation.

Skill discounting turns out to be even more exorbitant to immigrants' workers as they have further developed training. It is one clarification for the skill paradox that work rates for immigrants decline increasingly more comparative with those of practically identical local citizens, as skill levels increment. This devaluation-based skill contradiction can be considered as a workplace phenomenon. The further developed migrants' foreign skilled are, the more disruptive their acknowledgment by neighborhood foundations ends up being; if abilities are not perceived, odds of discovering business decline.

The course of discrimination has also been discovered by another volunteer participant $\mathrm{Mr}$. Saleem(pseudonym) who has worked as an engineer in parent country also faced difficulties in finding the relevant profession, he expressed his view that.

"Basically I was an engineer form one of the top universities in Pakistan, and had worked with multinational companies as an engineer, but I also faced difficulty in finding the job as a newly arrived immigrant but I could not find the suitable job for me according to my expectations, so I decided to switch my career from engineering to accountancy, which was not an easy decision but I had to make it to get job here in Canada ;" 


\section{Occupational mismatch:}

The work environment is the fundamental passage into another general public for most adult immigrants. "At work, they meet their neighborhood peers, update their professional skills, start up new cultural competence and improve their language capability; therefore, they create social and cultural identity in the new society and grow the points of confinement of their own personality" (Remennick 2013). However, numerous foreign trained professionals are not allowed the chance to enter the working environment since they can't discover appropriate work in their fields of specialization. In the course of recent decades, the labour market results of migrants to Canada have declined, and this descending direction of results agrees with upward patterns in educational levels (Creese and Wiebe 2012; Li 2003). Integration suggests that it is the duty of the receiving countries to guarantee that the proper privileges of immigrants are set up so that the individual has the plausibility of taking part in economic, social, cultural and community life (Entzinger and Biezeveld 2003). In any case, if skilled migrant individuals can't discover appropriate work in their fields of specialization, they might be less inclined to distinguish and interface to the fullest degree with the receiving society. In this regard, they are not incorporating into Canadian culture, but instead, adjusting to it. It isn't remarkable for continuing immigrants to switch occupations between employments. (Green 1999) found that occupational mobility is all in all more prominent for skilled immigrants of economic of migration contrasted with native born Canadians. His discoveries show that skilled immigrants push visibly toward progressively skilled occupations after some time which may just be a consequence of low section levels at appearance. Since Green's investigation depends on dependent of immigrants that arrived before 1991, very extraordinary as far as socio-demographic synthesis and human capital qualities contrasted with late companions, his discoveries may not so much mirror the current word related cohorts' 
patterns. For example, a later examination of match and mismatch of building occupations dependent on the 1996 Census (Boyd and Thomas 2001) shows that adult skilled immigrants who landed at age 28 or later and had foreign engineering degrees were less inclined to hold administrative and engineering positions.

Occupational attainment issues are additionally eminent among legitimate immigrants to the United States. (Akresh,2006) found that half of the immigrants who became permanent inhabitants in 1996 experienced occupational decreasing. The most influenced were migrants from Latin America and the Caribbean: seventy five percent of the highly educated immigrants from these locales worked in low-skilled employments. Education obtained in the United States was esteemed more than that gained abroad. Considering this examination, the likelihood of occupational coordinating subsequent to moving to the United States diminishes with the degree of foreign training: the most learned migrants experience a progressively significant occupational minimization. Despite that, the possibility of climbing the occupational scale increments with higher language capability and procurement of US training.

According to Mr. Khan(pseudonym) : "well, language ability is a key point for everyone, they are moving here, specially in Canadian society because in back in our country we people lack two things, which do not like soft skills and communication, how to communicate with the People. Soft skills are how much able you are to fit in to different communities, what quality you have is the employer who hire you he will see are you a team player, leader or how can you communicate electronically, how will you try to understand their conversations, so if we learn that language and it will give us this point that we can at least communicate people in a better way”.

Although, abilities transferability between information occupations is alluring on the grounds that it could help productivity and advancement potential, this condition scarcely applies to the highly 
trained professionals who are not set up in any occupation in Canada. In the event that employees can't rehearse in their occupations when entering the host country workplace, they become less aggressive after some time, which makes even less conceivable to defeat the 'transferability gap' that is relied upon to happen at immigration (Hawthorne 2016). There is a lot of proof that the human capital model that aids the choice of immigrants of economic class to Canada doesn't work perfectly in light of the fact that Canadian bosses want to select experts saw to be 'work prepared' instead of discover approaches to incorporate the new migrants. Conversely, since 1999, the Australian immigration policy chooses economic candidates dependent on 'employability' that is controlled by accreditation evaluation, being qualified in fields sought after and having great English capability. As exhibited in Hawthorne's recent findings (Hawthorne 2016) 'far more important extents of fresh debuts in Australia now than in Canada secure positions quickly, get to proficient or administrative status, gain significant compensations, and utilize their qualifications in work.

Continuing to the said questionnaire in view of addressing the difficulties in searching the job and answering the most asked question of how to overcome the difficulties and problem faced during the job hunt MR. Akhter (pseudonym) expressed his views that.

" The social networking plays a vital role for any new-comer from any diverse ethnic identity to extent social networking because your contacts may help you well in getting the desired professional job, why I insist that because social contacts within the community or outside the community provide you the sufficient ground for information that where job is located and what are the requirements are, that's why I urge that extend your social networking and try to own society to integrate economically” 


\section{Significance of social networking in job search:}

Networking is the age-old practice of building and sustaining individual and expert connections with an assortment of individuals to make a depository of resources, including contacts, information and support. Scholarly and academic literary works state that networking gives various gainful profession related results for the both people and organizations (Fugate 2004; Seibert 2001; Wolf and Moser2009). One explicit alluring result of social networking is improved employability, through the structure and support of contacts that can give important assets (Burt 1997; Granovetter 1977; Kanfer 2001; Van Hoye 2009). Most research expect an immediate connection among networking and employability, even though (Wanberg 2000), found that up to 36 percent of occupations are validated by means of networking, the outcomes were conflicting. They agree with others (Van Hoye 2009) explain that networking may be in a roundabout way identified with quest for new employment achievement and consequently question potential precursors. Study affirm that entrance to assets may be important, considering social and network capital hypotheses. networking makes numerous types of important social capital including promotion, presentations and tutoring that would somehow or another require the utilization of human or financial capital (Simon 2013). Social connections can give access to professional management that board assets that upgrade employability (Burt 1992; Granovetter 1977).

While conducting the separate interview with all of the volunteer participants very interesting and valuable findings were noted from one of the participants Mr. Khan (pseudonym), and he mentioned that: "Basically, I am from Pakistan and wend to London Uk for higher education in my field of profession. I had a dream to come to Canada and for that I made myself complete prepared to conquer all of the problems and difficulties which every new comer face in their early days of integration, so I decided to prepare myself to face Canadian employers from London UK, 
but in the end when I landed here in Canada I had already job in my hands because of my skill and foreign qualification from London UK"

These studies found that upon appearance in the host nation, immigrants' profit by contacts with co-ethnic loved ones who furnish them with information, data and other basic abilities which encourage the acclimation to the workplace.

As we have earlier mentioned that we had series of questions asked by the volunteer participants to address possible difficulties faced by the newly arrived foreign qualified skilled immigrants from Pakistan. Another participant of this research paper namely Mr. Iftikhar added his comments that:

"Canada is a land of dreams for me, yes indeed I appreciate that community development agencies provide and supply sufficient help to new immigrants from diverse community in a way that they provide the information and awareness about Canadian job experience by helping preparing the resumes and try to connect with potential employers from your profession, that's how you may able to find out your job of destination. I still remember my early days of arrival here in canada specialy in Toronto, the neighbourhood office formerly knows as TNO, Thorncliff neighbourhood office helped him a lot for connecting with appropriate employers according to my profession."

\section{Role of community development agencies:}

Immigration and settlement organizations are intended to address the numerous and differed requirements of newcomers (Drolet 2015). immigration, Refugees and Citizenship Canada (IRCC), once Citizenship and Immigration Canada (CIC), has received a modernized settlement approach with six selection criteria: (1) information and orientation, (2) language and skills 
development, (3) labour market participation, (4) community connections, (5) needs assessment and referrals, and (6) support services. Funding is accessible to help settlement projects and organizations in each center on competitive premise through calls or demands for recommendations. A system of settlement organizations is essential where newly arrived immigrants settle, and this incorporates littler networks (Drolet 2017b), where it might be even more testing to set up such a system.

In the underlying phases of settlement in new community, access to dependable/effective settlement agencies of community (ideally in the workers' very own language) in an inviting network, and access to sufficient, appropriate, and reasonable lodging are fundamental as essential courses for immigrants social, cultural, and economic integration into the host society.

Half of the respondents were at the conclusion of accreditation evaluation criteria because Canadian bosses or employers were definitely looking at Canadian evaluation. And respondents mentioned that such issue is one of the biggest hurdles for employment in your own profession, so we decided to take the inside from literature available and try to connect volunteer participants response with literature.

\section{Issues with Accreditation evaluation:}

Since 1967, individuals have been conceded as economic class of migrants to Canada under a classified points system, which accentuates the estimation of both their educational capabilities and their employment experience. Professionally skilled individuals living in Asian and African nations, consequently, get the certain message that Canadian employers and professional accreditation bodies will perceive and esteem their qualifications and work experience should they choose to move to Canada. Tragically, this suggestion is unwarranted, as the Canadian government 
has no components set up that will guarantee such acknowledgment. Without a doubt, the proof overwhelmingly proposes that Canadian businesses and expert accreditation bodies are not capable of assessing the value of foreign qualification along with professional experience acquired in nations from extremely separated parts of the world. In particular, a human capital way to deal with inquire about exploring this issue has demonstrated that foreign qualification and work experience are reliably underestimated, bringing about starting pay gaps that, for ongoing migrants, especially immigrants of colour are a lot bigger than previously noticed in the history (Basavarajappa and Jones 1999; Grant and Oertel 1998; Grant and Sweetman 2004; Li 2000, 2001, 2003; Pendakur and Pendakur 2001; Picot 2004).

As it is earlier mentioned in our paper with the help of respondent's feedback because most of them were urging on Canadian education and experience in order to opt employment in Canadian job market. We asked the question that how Canadian education is important so Mr. Habib(pseudonym) responded that.

"Canadian education system is very renowned and recognised all over the world and I am lucky enough to get Canadian education to fulfill the gap in order to integrate economically in Canadian society. I must appreciate Ryerson university of Toronto that has provided me platform to achieve career job in my profession.” 


\section{Role of Canadian education:}

Since the mid-1970s, Canada has selected enormous quantities of highly educated individuals whose knowledge and skills were relied upon to animate the nation's economic development and upgrade its competitiveness in global markets. A migration arrangement concentrated on human capital (Challinor 2011). Immigration made Canada one of the most appealing destination countries for profoundly qualified workers (for example people with college degrees finished in their countries of birth) looking for significant work and better future for their families. For as long as decade, over $60 \%$ of Canada's newcomers were conceded as economic immigrants, and a lion's share of them were chosen under the Skilled Worker class (for example required to pass a points test-rewarding education, work experience and language skills). The disturbing reduction in the level of Skilled Worker immigrants from 54\% in 2002 to 36\% in 2011 (CIC 2012) demonstrates Canadian government's endeavor to rebuild the nation's immigration policy.

The underutilisation of recent skilled workers' abilities is a significant worry in Canada. Despite the appeal for education and skills in the Canadian work environment, qualified immigrants neglect to discover jobs suitable to their qualification and professional experience (Picot 2004; Reitz 2007). Many are working in employments random to their pre-migration occupation endeavoring to acquire the Canadian work experience that is obviously or clandestinely required by Canadian employers. The human capital brought by highly qualified economic workers has been sporadically moved into the Canadian working environments where migrants' pre-migration skills, qualifications and skills are regularly ignored. Canada is selecting qualified immigrants, yet Canadian businesses are not especially intrigued to utilize their pre-migration experiences. It is likely to ask from skilled immigrants to speak, perform and think like a born Canadian citizen. Infect Canada is restricting its very own capability to advancement in a global economy. 
In this way, it isn't astonishing that highly qualified professionals, who experience a downgrading of their foreign human capital in the Canadian workplace, see interest in post secondary education (PSE) as an elective method for using their abilities, and an approach to gain some type of 'Canadian experience'. Although seeking after Canadian PSE is an any longer way to effective economic integration, it offers migrants a chance to utilize their pre-migration abilities and set up career and employment goals that go past insignificant work. Very nearly $66 \%$ of the workers who landed in 2000-2001 communicated enthusiasm for additional training in Canada (Statistics Canada 2005). About portion of the highly qualified professionals occupied with PSE inside 4 years of appearance (Adamuti-Trache 2011).

Skilled worker of economic class acknowledged by Canada based on their capabilities, training and aptitudes might be particularly inclined to lose their expert characters and sentiments of selfesteem when looked with challenges in finding appropriate work (Aycan and Berry 1996). Being utilized in one's field of preparing uplifts proficient personality, which thusly expands fearlessness and confidence, raises societal position and results in progressively social help and acknowledgment from others (Ross and Mirowsky 1995). Research recommends that acquiring palatable work approves the expectation and elation experienced in the beginning periods of immigration, however the failure to meet proficient objectives can bring about disappointment, despondency and nervousness (Majka and Mullan 1992). Researchers have hence discovered that job related issues are key markers of migrants' change in accordance with the accepting society (Majka and Mullan 1992; Aycan and Berry 1996; Neuwirth 1997). Distance from society is probably going to happen when there is a disparity between the ideal express that the accepting society esteems as the standard (for example having a better than average employment) and the accomplished condition of the workers (for example joblessness or underemployment) (Aycan and 
Berry 1996, p. 241). The more minimized the immigrants feel in the Canadian workplace, the less they wish to turn out to be a piece of the standard Canadian culture that they see has dismissed them (Grant and Nadin 2007).

In order to continue with the questionnaire, we asked the question from respondents that how government of Canada facilitates newly arrived skilled immigrants from all over the world.Mr. Iftikhar mentioned that.

"Thanks to the government of Canada because it provides financial assistance for newly immigrants who pursue their professional career by acquiring Canadian education. While studying in Ryerson university I applied for student financial assistance to cover my expenses because it was completely difficult to focus on study when you do not have any source of income in Canada but OSAP provides you enough funds by which you don't have a worry for your bills and kitchen expenses and that's the decisive initiative provided by Canadian government to ensure and secure the career and life of its human capital"

\section{Student financial assistance:}

Government sponsored student financial assistance programs are combination of federal and provincial levels. In many areas, government-ensured study loans are given to eligible students on an intrigue free premise while they are concentrating through the federal Canada Student Loans Program also a provincial-level loan program. These financial aids and loans from federal and provincial programs have experienced various important approach changes as of late including activities to give both in advance and back-end endowments to students.

Through the 1990s, the aggregate sum of non-repayable award help gave to students by the regions declined as award programs in various areas were revamped as credit programs (Junor and Usher 
2004). Two of the biggest areas, Quebec and British Columbia, diminished the sums gave to eligible students, however coordinate awards as of late as 2004 (Berger et al. 2009). Various provinces have recently reversed cuts to grants or re-introduced non-repayable grant programs. 


\section{Conclusion:}

We have discovered that, the most remarkable element of the highly qualified foreign workers from the Pakistan (South Asian nations) was their very solid propensity to choose Ontario as their underlying goal: more than $80 \%$ of them rolled up in Ontario. Our multivariate study uncovered this amazingly solid fixation in Ontario was basically because of two reasons. In the first place, they were firmly dependent upon the fascination of their co-ethnic networks, which were intensely amassed in Ontario. Second, they were emphatically dependent upon the constructive outcome of high pay level. Since Ontario has been one of the high pay areas for a long time, the workers' inclination for Ontario was resolved, to a huge degree, by its promising long-haul salary prospect.

We have additionally discovered that the underlying goal decisions of the newcomers being referred to reacted to changes in the spatial example of work development in a reasonable manner, their inclination was dependent upon the constructive outcome of job development rate. Considering the time range between the accommodation of the application for landed immigrant status and the allowing of the status, it is sensible that the impact of work development ended up being for the most part slacked by two years and, to a lesser degree, by three years.

Analysis of cases indicate that discrimination in employment is still a problem in Canada. Events of prejudice take place in different forms of organizations and industries in both the public and private sectors. It also involves people from different groups of education, experience and includes both white collar and blue-collar workers. This phenomenon is overly complex and multidimensional. There are several academic perspectives available that analyze the affects and outcomes of discrimination in the workplace. It may be inevitable that some sort of conflict arises in certain workplaces due to skilled based differences. Whether such conflict will lead to discrimination or harassment is dependent on several contextual factors. One of these factors is the 
availability of relevant organizational policies and penalties to prevent discrimination and the effectiveness of these policies in stopping this type of behaviour from spreading in the workplace. It is very important, therefore, that a policy of zero tolerance for such behaviour be established and enforced to create a healthy workplace that is free of skilled based discrimination and harassment.

In the light of responses from volunteer participants, this paper found that, adult immigrants' participation in education and training in Canada is an important part of the integration process and, almost upon arrival, many immigrants seem to be aware of the education and training opportunities offered by post-secondary institutions and other providers. Mr: Iftikhar added his views that, be prepared, become early guided by CIC programs \& initiative and get your licenced if you are an engineer and try to acquire Canadian education." This would involve greater institutional recognition of the diversity of the adult immigrant population in terms of education levels, language abilities, occupational profiles, and personal life circumstances that shape their unique motivations and actions. The response of adult educators is critical to the successful participation of immigrant learners. Lack of cultural awareness may raise communication barriers in the society. Lack of awareness of the complex issues that affect immigrant learners during the transition into the host society may diminish learners' chances to reach their professional goals. The study findings also revealed that Pakistani skilled worker ' choice of country is based upon popular discourses (e.g., the American/Canadian dream, recommendations from relatives and friends both at home and from abroad), rather than on current policy changes pertaining to economic immigrants and immigration in Canada. None of the volunteer participants interviewed for this study considered Canadian policy changes when making their decision to immigrating to Canada. However, it is also likely that these issues were not revealed because the interview questions did not specifically address the micro- and macro-level factors. These limitations should 
be addressed in further research focusing on Canada' immigration policy, as well as other countries. In-depth assessment of the effects that macro-level processes have on the decision to migrate abroad would provide a more comprehensive picture of the foreign qualified migration dynamics.

From this exploratory qualitative research on Pakistani skilled immigrant in Canada, few generalizations can be made. It is evident from the participants' narrations, however, that accreditation as well as settlement via employment is an individualized, isolated, and alienating process. The experiences of these highly qualified skilled immigrants in Canada are mixed, and all the respondents miss their former comfortable lives in Pakistan. Currently, all of the participants have stable jobs that have produced a newfound self-confidence and hold hope for a promising future for their children. The participants who have been living in Canada for more than ten years appear satisfied with their current lifestyle and their choice to migrate, in spite of the hardships they have encountered, because they feel that their children have benefited. Khan recaps: "well this is a big support from government of Canada, that allows any person from all around the world to make a new home in Canada, this is a big support and why we moved here, because we have a dream to built and give a good education to our kids and built a good society and living in a good atmosphere which we are missing back in country".

Future research is needed to understand the employment challenges and difficulties faced by highly qualified skilled immigrants from Pakistan to substantiate the findings of the present research. 


\section{Study questionnaire:}

\section{Canadian Immigration Experience: Case Studies of Pakistani Skilled Immigrants and}

\section{Their Job Experience.}

1. What is your name?

2. What is your Age?

3. What is your gender/sex?

4. What is your Ethnicity?

5. What is your immigration status in Canada, permanent resident or citizen of Canada?

6. What is your educational and professional background?

7. How many years you have lived in Canada?

8. Being skilled immigrant, what difficulties did you faced finding employment in your profession?

9. How did you overcome your difficulties?

10. Did you think that Canadian education and experience is necessary in order to get job in relevant field?

11. Did you change your career/field due to employment difficulties and how much you are satisfied?

12. Did you face any discrimination?

13. Did you balance opportunities compare to Ontario with other provinces?

14. What support did you received from Government \& communities' agencies?

15. Did you meet expectation that you brought from your home country in terms of socioeconomic stability? 
16. Do you think Government should do more for new immigrant in order to get them employment or connect to right employer?

17. Do you think volunteer or internship experience can lead to secure employment?

18. What do you think how language ability play a role to find right career?

19. Do you have any suggestions to add? 


\section{Study flyer}

Ryerson

University

\section{Canadian Immigration Experience: Case studies of Pakistani skilled immigrants and their job experience.}

Are you: Canadian Permanent resident or Canadian citizen, migrated from Pakistan as skilled immigrant, 25 years old or older, employed and not likely to become upset when asked straightforward questions, must be English speaking, located in GTA area?

\section{YES OR NO}

If you answered yes to the above noted questions you may volunteer. This study seeks minimum of 10 volunteer participants' to be interviewed \& audio recorded at discreet locations like private rooms in a Toronto library, community center or at Ryerson University as well, to share your job experience, expectations \& results. Your volunteer participation will involve one session of two hours (maximum) for career journey after landing here in Canada, the difficulties you have faced and how you achieved your job.

If you are interested in participating in this study, or would like more information, please contact: Mr. Saadat Hussain Qadri, Graduate student of Ryerson University and this study is the part 
of Graduate programme of Immigration \& settlement studies, 416- 979-5000, ext. 4836, saadat.qadri@ ryerson.ca

NOTE: This study is confidential, and the study received Ryerson REB approval and the study's REB file number (2019-253).

\section{Ryerson}

University

\section{Ryerson University}

\section{Consent Agreement}

You are being invited to participate in a research study. Please read this consent form so that you understand what your participation will involve. Before you consent to participate, please ask any questions to be sure you understand what your participation will involve.

Canadian Immigration Experience: Case studies of Pakistani skilled immigrants and their job experience.

INVESTIGATORS: This research study is being conducted by Graduate student Mr Saadat Hussain Qadri under supervision of Professor John Isbister, from master's programme Immigration \& Settlement Studies at Ryerson University.

If you have any questions or concerns about the research, please feel free to contact Saadat Hussain Qadri, saadat.qadri@ ryerson.ca, 416-979-5000 ext. 4836 
PURPOSE OF THE STUDY: The purpose of this study is to, examine the Canadian job and career experiences of skilled immigrants from Pakistan and challenges they face in Canada, while setting up a successful career path. The minimum of 10 respondents and maximum of 20 respondents will be included in this research study. The results will contribute into senior project, thesis or dissertation.

WHAT YOU WILL BE ASKED TO DO [OR] WHAT PARTICIPATION MEANS: If you volunteer to participate in this study, you will be asked to do the following things:

\section{Canadian Immigration Experience: Case Studies of Pakistani Skilled Immigrants and Their}

\section{Job Experience.}

If you are a Canadian Permanent resident or Canadian citizen and migrated from Pakistan as skilled immigrant, 25 years old or older, employed and not likely to become upset, when asked straightforward questions and must be English speaking, located in GTA area. You can volunteer to participate in this study.

This study seeks minimum of 10 volunteer participant's to be interviewed \& audio recorded at discreet locations like private rooms in a Toronto library, community center or at Ryerson University as well, (including the possibility of phone/Skype interviews, if applicable) to share your job experience, expectations \& results. While being interviewed, your demographic data will be collected/used such as name, age, gender, immigration status here in Canada.

Your volunteer participation will involve one session of two hours (maximum) for career journey after landing here in Canada \& below mentioned kind of questions will be asked in interview: 
(1) Being skilled immigrant, what difficulties did you faced finding employment in your profession?

(2) How did you overcome your difficulties?

Your participation/interview will be used to inform a graduate research paper in graduate research study after completion.

\section{INSTRUCTIONS FOR VOLUNTEER PARTICIPANTION:}

1. You have the right to skip answering a question or withdraw from participation, either temporarily or permanently at any stage of interview process.

2. You have right to review/edit transcripts within 48 hours of time.

3. You will have 48 hours of time to withdraw from participation from this study even after interview. If so, please contact Graduate student of Ryerson University Mr. Saadat Hussain Qadri, saadat.qadri@ ryerson.ca or 416-979-5000, ext. 4836

4. The forms will be stored \& locked in filing cabinet of supervisor's office on campus and audio recording will be stored in Ryerson google drive account of graduate student.

5. The audio recording will be permanently deleted from Ryerson google drive account of graduate student "immediately" after transcribing into written form and forms will be discarding from Ryerson secure shredding bin on completion of the study.

6. The data will be destroyed around September $15^{\text {th }}, 2019$. 
7. You will have the access to the study findings at Ryerson digital repository by clicking the link https://digital.library.ryerson.ca/ and click on the "BROWS" option on left side of the web page, then click at the programs(Themes) option, you will have list of programs available in alphabetical order, simply click the "I" alphabet, this option will take you to the program of Immigration and settlement studies, where you will find research study named as "Canadian Immigration Experience: Case studies of Pakistani skilled immigrants and their job experience"

\section{POTENTIAL BENEFITS:}

This study will help to present reasonable contribution in further research and literature in order to concentrate on the experiences of Pakistani immigrants. Who arrive with diverse stages of education and with different classes of immigration? How Pakistani professionals from different occupations achieve their success and how difficult to make their dreams true. Settling in diverse sectors of the employment and labour market, secondly, this paper will also explore the approaches to develop in job search challenges.

\section{WHAT ARE THE POTENTIAL RISKS TO YOU AS A PARTICIPANT?}

The generic risks like Psychological risk (e.g. feeling anxious, upset or uncomfortable) and Personal identity being revealed (e.g. participant being identified either directly or inadvertently) because of the personal nature of the questions asked. Being a participant, you may reflect on unpleasant memories while responding to a questionnaire or interview. Therefore, you will be informed of the potential for discomfort and told that if being a participants begin to feel uncomfortable, you may assign pseudonyms to yourself to protect your identity from being 
revealed and skip answering a question or stop participation, either temporarily or permanently at any stage of interview process or within 48 hours of time after interview.

CONFIDENTIALITY: The pseudonyms will be assigned and if/how participants can indicate their preference of whether or not their real name is used in published material. If the latter is an option, please include a checkbox on the signatory page for participants to opt in or out.

The participants of this study will be audio recorded and the participants has right to review/edit the recordings or transcripts. All recording will be stored in Ryerson google drive account of the graduate student, only principle investigator \& co-investigator (Supervisor) will have access to the raw and transcribed recordings. All recording will be destroyed after study is completed.

INCENTIVES FOR PARTICIPATION: The participant will not be paid to participate in this study.

COSTS TO PARTICIPATION: This study is unfunded therefore no costs will be paid to participants for their volunteer participation.

\section{COMPENSATION FOR INJURY:}

By agreeing to participate in this research, you are not giving up or waiving any legal right in the event that you are harmed during the research.

\section{VOLUNTARY PARTICIPATION AND WITHDRAWAL:}

Participation in this study is completely voluntary. You can choose whether to be in this study or not. If any question makes you uncomfortable, you can skip that question. You may stop participating at any time during interview. If you choose to stop participating, you may also choose to not have your data included in the study. Your choice of whether or not to participate will not 
influence your future relations with Ryerson University or the investigators Mr. Saadat Hussain Qadri involved in the research.

QUESTIONS ABOUT THE STUDY: If you have any questions about the research now, please ask. If you have questions later about the research, you may contact. Mr. Saadat Hussain Qadri, Graduate student of Immigration \& settlement studies, 416-979-5000, ext.4836,saadat.qadri@ryerson.ca. Supervisor: John Isbister, Professor of economics, 4169795000, Ext 3408, isbister@ ryerson.ca

This study has been reviewed by the Ryerson University Research Ethics Board. If you have questions regarding your rights as a participant in this study, please contact:

\author{
Research Ethics Board \\ c/o Office of the Vice President, Research and Innovation \\ Ryerson University \\ 350 Victoria Street \\ Toronto, ON M5B 2K3 \\ 416-979-5042 \\ rebchair@ryerson.ca
}

Name of Participant (please print)

Date 


\section{CONFIRMATION OF AGREEMENT:}

\section{Canadian Immigration Experience: Case studies of Pakistani skilled immigrants and their} job experience.

Your signature below indicates that you have read the information in this agreement and have had a chance to ask any questions you have about the study. Your signature also indicates that you agree to participate in the study and have been told that you can change your mind and withdraw your consent to participate at any time. You have been given a copy of this agreement.

You have been told that by signing this consent agreement you are not giving up any of your legal rights.

Name of Participant (please print)

Signature of Participant

Date

- Audio Recorded 
I agree to be "audio-recorded" for the purposes of this study. I understand how these recordings will be stored and destroyed.

Signature of Participant

Date

- Assigned pseudonym

- Assigned Real name
(YES OR NO)

(YES OR NO )

I agree to be assigned pseudonym or real name for the purposes of this study. I understand how these Real name or pseudonym will be stored and destroyed.

Signature of Participant

Date 


\section{$\underline{\text { References: }}$}

- Adamuti-Trache, M. (2011). First 4 years in Canada: Post-secondary education pathways of highly educated immigrants. Journal of International Migration and Integration/Revue de l'integration et de la migration internationale, 12(1), 61-83.

- Akresh, I. (2006). Occupational Mobility among Legal Immigrants to the United States. The International Migration Review, 40(4), 854-884. Retrieved January 28, 2020, from www.jstor.org/stable/27645637

- Asanin Dean, J., and K. Wilson. 2009. "Education? It is irrelevant to my job now. It makes me very depressed.": Exploring the health impacts of under/unemployment among highly skilled recent immigrants in Canada. Ethnicity \& Health 14(2): 185-204.

- Aycan, Z., \& Berry, J. W. (1996). Impact of employment-related experiences on immigrants' psychological well-being and adaptation to Canada. Canadian Journal of Behavioural Science/Revue canadienne des sciences du comportement, 28(3), 240.

- Bauder, H. 2003. "Brain abuse", or the devaluation of immigrant labour in Canada. Antipode 35(4): 699-717.

- Berger, J., Motte, A., \& Parkin, A. (Eds.). (2009). The price of knowledge: Access and student finance in Canada. Canada Millenium Scholarship Foundation.

- Binggeli, S., Dietz, J., \& Krings, F. (2013). Immigrants: A forgotten minority. Industrial and Organizational Psychology, 6(1), 107-113.

- Boyd, M., and M. Vickers. 2000. 100 years of immigration in Canada. Canadian Social Trends 2-12. Ottawa: Statistics Canada. http://www5.statcan.gc.ca.ezproxy.lib.ryerson.ca/olc-cel/olc.action?ObjId=11008-X20000025164\&ObjType $=47 \&$ lang $=$ en . 
- Boyd, M., \& Thomas, D. (2001). Match or mismatch? The employment of immigrant engineers in Canada's labor force. Population Research and Policy Review, 20(1-2), 107133.

- Burt, R. S. (1997). The contingent value of social capital. Administrative science quarterly, 339-365.

- Castles, S., \& Kosack, G. (1973). Immigrant workers and class structure in Western Europe. Oxford University Press.

- Castles, S. (2004). Why migration policies fail. Ethnic and racial studies, 27(2), 205-227.

- Creese, G., \& Wiebe, B. (2012). 'Survival employment': Gender and deskilling among African immigrants in Canada. International migration, 50(5), 56-76.

- Challinor, A. E. (2011). Canada's immigration policy: A focus on human capital. Migration Information Source, 1(8).

- Drolet, J., Hamilton, L. K., \& Esses, V. M. (2015). Labour market integration project: Improving collaboration in Calgary for better employment outcomes for immigrants. Immigrant Sector Council of Calgary.

- Drolet, J. (2017). Building inclusive and welcoming communities for immigrants. Working with immigrants and refugees: Issues, theories and approaches for social work and human service practice. Oxford University Press Canada.

- Guo, S. (2013). The changing face of work and learning in the context of immigration: The Canadian experience. Journal of Education and Work, 26(2), 162-186.

- Guo S, Economic Integration of Recent Chinese Immigrants in Canada's Second-Tier Cities: The Triple Glass Effect and Immigrants’ Downward Social Mobility. Canadian Ethnic Studies, v.45 (3), p.95, 2013a, 
- Guo, Y. (2009). Racializing immigrant professionals in an employment preparation ESL program. Cultural and Pedagogical Inquiry, 1(2).

- Entzinger, H., \& Biezeveld, R. (2003). Benchmarking in immigrant integration.

- Esses, V. M., Dietz, J., \& Bhardwaj, A. (2004). Race, prejudice, and the evaluation of immigrant skills. In International Journal of Psychology (Vol. 39, No. 5-6 Special Issue: Abstracts of the XXVIII INTERNATIONAL CONGRESS OF PSYCHOLOGY).

- Esses, V. M., Dietz, J., \& Bhardwaj, A. (2006). The Role of Prejudice in the Discounting of Immigrant Skills.

- Fang, T., Samnani, A. K., Novicevic, M. M., \& Bing, M. N. (2013). Liability-offoreignness effects on job success of immigrant job seekers. Journal of World Business, 48(1), 98-109.

- Fugate, M., Kinicki, A. J., \& Ashforth, B. E. (2004). Employability: A psycho-social construct, its dimensions, and applications. Journal of Vocational behavior, 65(1), 14-38.

- Girard, M., and M. Smith. 2013. Working in a regulated occupation in Canada: An immigrant-native born comparison. International Journal of Migration \& Integration 14(2): 219-244.

- Green, D. A. (1999). Immigrant occupational attainment: Assimilation and mobility over time. Journal of Labor Economics, 17(1), 49-79.

- Granovetter, M. S. (1977). The strength of weak ties. In Social networks (pp. 347-367). Academic Press.

- Grant, P. R., \& Nadin, S. (2007). The credentialing problems of foreign trained personnel from Asia and Africa intending to make their home in Canada: A social psychological 
perspective. Journal of International Migration and Integration/Revue de l'integration et de la migration internationale, 8(2), 141-162.

- Grant, H. M., \& Oertel, R. R. (1998). Diminishing returns to immigration? Interpreting the economic experience of Canadian immigrants. Canadian Ethnic Studies Journal, 30(3), 56-78.

- Grant, H., \& Sweetman, A. (2004). Introduction to economic and urban issues in Canadian immigration policy. Canadian Journal of Urban Research, 1-24.

- Haider, M. (2012). Pakistani-Canadians: Falling below the poverty line. Dawn, May 16.

- Hawthorne, L. (2016). Foreign credential recognition and assessment: An introduction. Available at SSRN 2808951.

- Hawthorne, L. (2016). Labour market outcomes for migrant professionals: Canada and Australia compared. Available at SSRN 2808943.

- Junor, S., \& Usher, A. The price of knowledge 2004: access and student finance in Canada/written by Sean Junor, Alex Usher. Millennium research series.

- Jupp, J. (2002). From white Australia to Woomera: The story of Australian immigration. Cambridge University Press.

- Kanfer, R., Wanberg, C. R., \& Kantrowitz, T. M. (2001). Job search and employment: A personality-motivational analysis and meta-analytic review. Journal of Applied psychology, 86(5), 837.

- Kobayashi, A., W. Li, and C. Teixeira. 2012. Immigrant geographies: Issues and debates. In Immigrant geographies of North American cities, ed. C. Teixeira, W. Li, and A. Kobayashi. Don Mills, ON: Oxford University Press, xiv-xxxviii. 
- Konadu-Agyemang, K., B. K. Takyi, and J. A. Arthur. 2006. The new African diaspora in North America: Trends, community building and adaptation. Lanham, MD: Lexington Books.

- Li, C., Gervais, G., \& Duval, A. (2006). The dynamics of overqualification: Canada's underemployed university graduates (pp. 11-621). Ottawa: Statistics Canada.

- Li, P. S., \& Halli, S. S. (2003). Destination Canada: Immigration debates and issues. Canadian Ethnic Studies, 35(1), 185.

- Li, P. S. (2000). Earning disparities between immigrants and native-born Canadians. Canadian Review of Sociology/Revue canadienne de sociologie, 37(3), 289311.

- Li, P. S. (2001). The market worth of immigrants' educational credentials. Canadian Public Policy/Analyse de Politiques, 23-38.

- Li, P. S. (2003). Initial earnings and catch-up capacity of immigrants. Canadian Public Policy/Analyse de Politiques, 319-337.

- Li, P. S. (2008). The role of foreign credentials and ethnic ties in immigrants' economic performance. Canadian Journal of Sociology, 33(2).

- Majka, L., \& Mullan, B. (1992). Employment retention, area of origin and type of social support among refugees in the Chicago area. International Migration Review, 26(3), 899926.

- Nerad, S., and A. Janczur. 2000. Primary health care with immigrant and refugee populations - Issues and challenges. Australian Journal of Primary Health 6(4): 222-229.

- Neuwirth, G. (1997). Indicators of integration. INSCAN, 10(3), 5-7. 
- Neuman, W. L., \& Neuman, L. W. (2006). Workbook for Neumann Social research methods: qualitative and quantitative approaches. Allyn \& Bacon.

- Pendakur, R. (2001). Immigrants and the labour force: Policy, regulation, and impact. McGill-Queen's Press-MQUP.

- Picot, G. (2004). The deteriorating economic welfare of Canadian immigrants. Canadian Journal of Urban Research, 25-45.

- Qureshi, M.N., Ali, K. and Khan, I.R. (2010), "Political instability and economic development Pakistan time-series analysis", International Research Journal of Finance and Economics, Vol. 56, pp. 179-192.

- Reitz, J. G. (2007). Immigrant employment success in Canada, Part I: Individual and contextual causes. Journal of International Migration and Integration/Revue de l'integration et de la migration internationale, 8(1), 11-36.

- Reitz, J. G. (2007). Immigrant employment success in Canada, part II: Understanding the decline. Journal of International Migration and Integration/Revue de l'integration et de la migration internationale, 8(1), 37-62.

- Remennick, L. (2013). Professional identities in transit: Factors shaping immigrant labour market success. International Migration, 51(1), 152-168.

- Ross, C. E., \& Mirowsky, J. (1995). Does employment affect health? Journal of Health and social Behavior, 230-243.

- Salaff, J., Greve, A., \& Ping, L. X. L. (2002). Paths into the economy: Structural barriers and the job hunt for skilled PRC migrants in Canada. International Journal of Human Resource Management, 13(3), 450-464. 
- Seibert, S. E., Kraimer, M. L., \& Liden, R. C. (2001). A social capital theory of career success. Academy of management journal, 44(2), 219-237.

- Setia, M. S., Lynch, J., Abrahamowicz, M., Tousignant, P., \& Quesnel-Vallee, A. (2011). Self-rated health in Canadian immigrants: analysis of the Longitudinal Survey of Immigrants to Canada. Health \& Place, 17(2), 658-670.

- Shan, H. (2013). Skill as a relational construct: hiring practices from the standpoint of Chinese immigrant engineers in Canada. Work, employment and society, 27(6), 915-931.

- Statistics Canada. Special Surveys Division. (2005). Longitudinal survey of immigrants to Canada: A portrait of early settlement experiences. Statistics Canada.

- Statistics Canada (2015), "Profile of internationally-educated immigrants aged 25 to 64", available at: www.statcan.gc.ca/pub/81-595-m/2010084/tbl/tbl6-eng.htm (accessed 12 September,2016).

- Statistics Canada (2016a), "NHS profile", Canada 2011, avalable at: www12.statcan.gc.ca/nhs-enm/2011/dp $\mathrm{pd} /$ prof/details/page.cfm?Lang $=\mathrm{E} \& \mathrm{Geo} 1=\mathrm{PR} \&$ Code $1=01 \&$ Data $=$ Count $\&$ SearchText $=01$ $\&$ SearchType $=$ Begins $\&$ SearchPR $=01 \& A 1=$ Immigration $\% 20$ and $\% 20$ citizenship $\& B 1=A 11$ \& Custom=\&amp; TABID=3 (accessed 14 September 2016).

- Statistics Canada (2016b), "Immigration and ethnocultural diversity in Canada", available at: www12. statcan.gc.ca/nhs-enm/2011/as-sa/99-010-x/99-010-x2011001eng.cfm (accessed 14 September,2016]

- Subedi, R. P., \& Rosenberg, M. W. (2014). Determinants of the variations in selfreported health status among recent and more established immigrants in Canada. Social Science \& Medicine, 115, 103-110. 
- Picot, G. (2004). The deteriorating economic welfare of Canadian immigrants. Canadian Journal of Urban Research, 25-45.

- Thorbjörnsson, C. B., Michélsen, H., \& Kilbom, Å. (1999). Method for retrospective collection of work-related psychosocial risk factors for musculoskeletal disorders: Reliability and aggregation. Journal of Occupational Health Psychology, 4(3), 193.

- Turchick Hakak, L., \& Al Ariss, A. (2013). Vulnerable work and international migrants: A relational human resource management perspective. The International Journal of Human Resource Management, 24(22), 4116-4131.

- Van Hoye, G., Van Hooft, E. A., \& Lievens, F. (2009). Networking as a job search behaviour: A social network perspective. Journal of Occupational and Organizational Psychology, 82(3), 661-682.

- Wanberg, C. R., Kanfer, R., \& Banas, J. T. (2000). Predictors and outcomes of networking intensity among unemployed job seekers. Journal of Applied Psychology, 85(4), 491.

- Wald, S., and T. Fang. 2008. Overeducated immigrants in the Canadian labour market: Evidence from the workplace and employee survey. Canadian Public Policy 34(4): 457479.

- Wolff, H. G., \& Moser, K. (2009). Effects of networking on career success: a longitudinal study. Journal of Applied Psychology, 94(1), 196.

- Xu, L. 2012. Who drives a taxi in Canada? Citizenship and Immigration Canada. http://www.cic.gc.ca.ezproxy.lib.ryerson.ca/english/pdf/research-stats/taxi.pdf.

- Zaman, H. (2006). Breaking the iron wall: Decommodification and immigrant women's labor in Canada. Lexington Books. 
- Zikic, J., Bonache, J. and Cerdin, J.L. (2010), “Crossing national boundaries: a typology of qualified immigrants' career orientations", Journal of Organizational Behaviour, Vol. 31 No. 5, pp. 667-686. 